\title{
Evaluation of ApoE Genotyping Using Saliva-Derived DNA
}

Takuya Kushioka', Makoto Ocho', Yukihiko Ito', Takafumi Yokokawa², Kei Yui ${ }^{1}$ and Yoshimitsu Yamasaki ${ }^{2 *}$

${ }^{1}$ FANCL Corporation, 12-13 Kamishinano, Totsuka-ku, Yokohama, Kanagawa, Japan

${ }^{2}$ Signpost Corporation, 2-2-5 Doshomachi, Chuo-ku, Osaka, Osaka, Japan

\begin{abstract}
Background: The single nucleotide polymorphism (SNP) regions (rs429358 and rs7412) that define the ApoE genotype have a high GC content, which makes genotyping difficult. Blood samples are mainly used for $A p o E$ genotyping, and saliva has also been used in recent years. However, the equivalency of genotyping results using saliva samples has not been verified. Hence, we evaluated the equivalency of the genotyping results for saliva samples by two genotyping methods such as Sanger sequencing and restriction fragment length polymorphism (RFLP).

Methods: Saliva and blood samples were collected from 51 subjects. The yield and quality of the extracted DNA were assessed. The regions around ApoE SNP were amplified by PCR, and genotyping was performed by Sanger sequencing and RFLP.

Results: The mean concentration of saliva-derived genomic DNA was lesser than that of blood-derived DNA, and the quality of many saliva-derived DNA samples was poor. Regarding genotyping, the results of saliva-derived genomic DNA were $100 \%$ consistent with those of blood-derived DNA. Also, the results were $100 \%$ consistent between the two methods.

Conclusion: Although the mean concentration of saliva-derived genomic DNA was lower than that of blood-derived DNA, and the variation in the quality of saliva-derived genomic DNA was higher than that of blood-derived DNA, the $A P O E$ genotyping results were equivalent for both the samples.
\end{abstract}

Keywords: ApoE genotype; Genetic testing; Saliva genomic DNA

\section{Introduction}

The apolipoprotein $\mathrm{E}(A p o E)$ gene is located on chromosome 19q13.2. It consists of four exons and three introns with 3597 base pairs and produces 299-amino acid polypeptide [1]. It has three alleles (E2, E3 and E4), differing by the presence of either $\mathrm{C}$ or $\mathrm{T}$ nucleotides at codons 112 and 158 in the fourth exon. There are six combinations of the alleles (E2/E2, E3/E3, E4/E4, E3/E2, E4/E3 and E4/E2) [2,3]. The ApoE genotype frequencies in Japanese population were reported to be $0.3 \%$ for $\mathrm{E} 2 / \mathrm{E} 2$, $6.1 \%$ for $\mathrm{E} 3 / \mathrm{E} 2,71.9 \%$ for $\mathrm{E} 3 / \mathrm{E} 3,0.7 \%$ for $\mathrm{E} 4 / \mathrm{E} 2,19.3 \%$ for $\mathrm{E} 4 / \mathrm{E} 3$, and $1.7 \%$ for $\mathrm{E} 4 / \mathrm{E} 4$. The ApoE allele frequencies were 3.7\%, 84.9\%, and $11.7 \%$ for E2, E3 and E4, respectively. A racial difference has been reported in the $A p o E$ allele frequencies [4-6]. The relationships of $A p o E$ with diseases (e.g. type III hyperlipoproteinemia, coronary heart disease, stroke, peripheral arterial disease and diabetes mellitus) that are associated with increased lipid and cholesterol levels and with Alzheimer's disease have been studied. Many studies have reported that the ApoE E4 gene is a risk factor for Alzheimer's disease across several ethnicities (Caucasians, Japanese, Latin Americans and Hispanics) [7-11].

Generally, Sanger sequencing is used for $A p o E$ genotyping. In this method, the regions with rs429358 and rs7412 in exon 4 of ApoE are amplified by PCR using the DNA extracted from blood samples as a template. Other methods include the amplification refractory mutation system (ARMS) [12], restriction fragment length polymorphism (RFLP) [13], real time-PCR (RT-PCR) [14], reverse hybridization (RH) [15] and fluorescence polarization (FP) [16].

Blood samples with a reasonable quality and amount of genomic DNA can be obtained and are generally used as a source of genomic DNA for genotyping. However, PCR success rate of ApoE tends to be low owing to its high GC content around the single nucleotide polymorphism (SNP) regions rs429358 and rs7412 in exon 4 [17]. In recent years, saliva samples have emerged as an alternative to blood as a source of genomic DNA. It has several advantages compared with blood sampling, including less invasiveness, low infection risk, and easy transportation. Stable saliva samples can be stored at room temperature for a long time. Also, in contrast to blood sampling, a trained professional is not required to collect saliva samples. However, it is unknown whether the quality of DNA extracted from saliva is lower than that extracted from blood because DNA isolated from saliva is contaminated with food residues or DNA derived from oral bacteria $[18,19]$.

In ApoE genotyping, the results obtained for genomic DNA extracted from saliva samples have been reported [20]. However, the comparison of these results with those of blood samples has not been reported. Because the concentration and quality of genomic DNA extracted from saliva are lower than those of genomic DNA extracted from blood, the accuracy of genotyping results should be carefully investigated. Hence, we evaluated the genotyping results using two methods, Sanger sequencing and RFLP, for both blood and saliva samples.

\section{Materials and Methods}

\section{Verification design and subject information}

This study was conducted in accordance with the approval of

*Corresponding author: Yoshimitsu Yamasaki, Signpost Corporation, 2-2-5 Doshomachi, Chuo-ku, Osaka, Osaka, Japan, Tel: +81-6-6229-8585; Fax: +81-66229-8787; E-mail: yamasaki@signpostcorp.com

Received October 07, 2017; Accepted November 29, 2017; Published January 05, 2018

Citation: Kushioka T, Ocho M, Ito Y, Yokokawa T, Yui K, et al. (2017) Evaluation of ApoE Genotyping Using Saliva-Derived DNA. J Clin Med Genomics 6: 149. doi: 10.4172/2472-128X.1000149

Copyright: () 2018 Kushioka T, et al. This is an open-access article distributed under the terms of the Creative Commons Attribution License, which permits unrestricted use, distribution, and reproduction in any medium, provided the original author and source are credited. 
the ethics committee of the FANCL Corporation, Declaration of Helsinki (adopted in June 1964, amended in October 2013), Personal Information Protection Act, Ethical Guidelines for Medical and Health Research Involving Human Subjects (Public Notice of the Ministry of Education, Culture, Sports, Science and Technology, and Ministry of Health, Labor, and Welfare No. 3 of 2014) and Ethical Guidelines for Human Genome/Gene Analysis Research (Public Notice of the Ministry of Education, Culture, Sports, Science and Technology, Ministry of Health, Labor and Welfare and the Ministry of Economy, Trade and Industry No. 1 of 2013). The subjects included 51 Japanese males and females.

\section{Sample}

Both blood and saliva samples were collected from each of the 51 subjects. Using a $2 \mathrm{~mL}$ VENOJECT ${ }^{\circ}$ II blood collection tube, $2 \mathrm{~mL}$ of blood was collected from the cubital vein and it was mixed well, frozen and stored. Using the sampling kit Oragene ON-500 (Genotec Inc.), $0.5 \mathrm{~mL}$ of saliva sample was collected. Eating, drinking, smoking, and chewing gum were prohibited from 30 min before saliva collection.

\section{DNA extraction}

Blood sample $(300 \mu \mathrm{L})$ was mixed with $30 \mu \mathrm{L}$ Proteinase $\mathrm{K}$ and $300 \mu \mathrm{L}$ lysis buffer, and an isothermal reaction was performed in an aluminum block at $56^{\circ} \mathrm{C}$ for $20 \mathrm{~min}$. Subsequently, the whole sample was dispensed into a Maxwell 16 LEV Cartridge (Promega) well and processed using Maxwell 16 (Promega), an automated nucleic acid extraction instrument. DNA was extracted in LEV DNA mode.

The saliva sample was subjected to isothermal reaction in a constant temperature air-blower at $50^{\circ} \mathrm{C}$ for $16 \mathrm{~h}$ or longer. Next, DNA was extracted using the same method as for blood samples.

\section{Measurement of DNA concentration and DNA quality}

The concentration of genomic DNA extracted from the sample was measured by fluorescence intensity in a plate reader using QuantiT PicoGreen dsDNA Assay Kit (Life Technologies). The quality of the extracted genomic DNA was evaluated by visual inspection of the $1 \%$ agarose gel electrophoresis image.

\section{ApoE gene genotyping}

Sanger sequence method: PCR was performed using two types of primers (101F primer: 5'-GCCTACAAATCGGAACTGGA-3' and 102R primer: $5^{\prime}$-CTGCCCATCTCCTCCATC-3') with the following protocol: $94^{\circ} \mathrm{C}$ for $2 \mathrm{~min} \rightarrow\left(98^{\circ} \mathrm{C}\right.$ for $10 \mathrm{~s} \rightarrow 58^{\circ} \mathrm{C}$ for $30 \mathrm{~s} \rightarrow 68^{\circ} \mathrm{C}$ for $30 \mathrm{~s}) \times 35$ cycles. Then, the PCR products were purified using ExoSAPIT (Affymetrix), and a cycle sequencing reaction was performed using BigDye Terminator v3.1 Cycle Sequencing Kit (Life Technologies) and a primer (5'-GGAACTGGAGGAACAACTGA-3'). After purification using BigDye ${ }^{\circ}$ Xerminator ${ }^{\text {Th }}$ Purification Kit (Life Technologies), capillary electrophoresis was performed on a 3730xl DNA Analyzer (Life Technologies).

RFLP method: PCR was performed using two types of primers (201F: 5'-ACAGAATTCGCCCCGGCCTGGTACAC-3' and 202R: 5'-TAAGCTTGGCACGGCTGTCCAAGGA-3') with the following protocol: $95^{\circ} \mathrm{C} 5 \mathrm{~min} \rightarrow\left(95^{\circ} \mathrm{C}\right.$ for $1 \mathrm{~min} \rightarrow 65^{\circ} \mathrm{C}$ for $1 \mathrm{~min} \rightarrow 70^{\circ} \mathrm{C}$ for $2 \mathrm{~min}) \times 40$ cycles. After the fragmentation of PCR products $\left(37^{\circ} \mathrm{C}\right.$, $12 \mathrm{~h}$ onward) by restriction enzyme Hha I, gel electrophoresis was performed using $2 \%$ agarose gel. From the results of electrophoresis, ApoE genotype of the samples was determined by visual inspection.

\section{Results}

\section{Comparison of the concentration and quality of genomic DNA extracted from saliva and blood}

The mean (SD) concentrations of genomic DNA extracted from blood and saliva were $156.1 \mathrm{ng} / \mu \mathrm{L}$ (54.2) and $46.3 \mathrm{ng} / \mu \mathrm{L}$ (47.7), respectively. The concentration of genomic DNA extracted from saliva was lower than that from blood. One of the genomic DNA samples extracted from blood obtained mean $+2 \mathrm{SD}$ or more of the yield (Sample ID: 00018). Three of the genomic DNA samples extracted from blood obtained mean +2 SD or more of the yield (Sample ID: 00008, 00013 and 00047). In addition, the concentration distributions of genomic DNA extracted from saliva were biased toward the regions with low concentrations (Tables 1 and S1 and Figure S1).

The quality of extracted genomic DNA was evaluated by agarose gel electrophoresis. Low-quality sample were not found in 51 genomic DNA samples extracted from blood, whereas 9 low-quality samples $(17.6 \%)$ were found in 51 genomic DNA samples extracted from saliva. The position of the major band of extracted genomic DNA was $23 \mathrm{~kb}$ or more for all the samples (Figure S2 and Table S2).

\section{ApoE genotyping}

PCR was performed using the extracted genomic DNA from saliva samples, with blood sample as a template, and subsequently, genotyping was carried out by Sanger sequencing and RFLP. As a result, PCR products were obtained for all the samples (PCR products from $101 \mathrm{~F}$ and $102 \mathrm{R}$ primers, $452 \mathrm{bp}$; from $201 \mathrm{~F}$ and 202R primers: $244 \mathrm{bp}$ ) (Figures S3 and S4). However, among the PCR products amplified with $201 \mathrm{~F}$ and $202 \mathrm{R}$ primers, bands of 244 and $500 \mathrm{bp}$ were observed in one sample (saliva; Index Code: 55, Sample ID: 00010).

Using Sanger sequencing and RFLP, the genotype of all the samples could be identified and waveform sequences in all samples had good quality (data not shown) (Figure S5). In both the methods, the genotyping results of saliva samples were $100 \%$ consistent with the results of blood samples (Tables 2 and S3).

\section{Discussion}

This study revealed that the accuracy of genotyping results of $A p o E$ gene from saliva samples was similar to that of blood samples. Appropriate PCR products were obtained in all samples and genotyping results of the $A p o E$ gene were consistent for both the methods. The genotype frequency data were similar to the previously reported data of Japanese population; therefore, the results were considered to be valid [6].

\begin{tabular}{|c|c|c|}
\hline & \multicolumn{2}{|c|}{ Sample } \\
\hline & Blood & Saliva \\
\hline Sample Numbers & 51 & 51 \\
\hline DNA concentration $(\mathrm{ng} / \mathrm{\mu L})$ & & $29.0(5.4-251.6)$ \\
\hline Median (min-max) & $149.1(45.2-397.6)$ & $46.3(47.7)$ \\
\hline Mean (SD) & $156.1(54.2)$ & $17.6(9)$ \\
\hline Low-quality DNA \% (no.) & $0(0)$ & \\
\hline
\end{tabular}

Table 1: Characteristics of blood and saliva samples.

The concentration and quality of collected genomic DNA are summarized. Median DNA concentration (min: minimum value; max: maximum value) and mean DNA (SD) concentrations are shown. Low-quality DNA was evaluated by the presence or absence of smear (samples with sharper bands to the end of electrophoresis), extra bands, and samples with different band locations (except $23 \mathrm{~kb}$ ). Also, the percentages of DNA are shown (no.: number of samples) 


\begin{tabular}{|c|c|c|c|c|c|c|c|c|}
\hline \multirow{3}{*}{$\begin{array}{c}\text { ApoE } \\
\text { genotype }\end{array}$} & \multicolumn{6}{|c|}{ Genotyping method } & \multirow{3}{*}{$\begin{array}{c}\text { Genotype } \\
\text { frequency } \%\end{array}$} & \multirow{3}{*}{$\begin{array}{c}\text { Genotype } \\
\text { frequency \% } \\
\text { (Eto et al. [6]) }\end{array}$} \\
\hline & \multicolumn{3}{|c|}{ Sanger Sequence } & \multicolumn{3}{|c|}{ RFLP } & & \\
\hline & Blood DNA & Saliva DNA & Accuracy \% & Blood DNA & Saliva DNA & Accuracy \% & & \\
\hline$\varepsilon 2 / \varepsilon 2$ & 0 & 0 & 100 & 0 & 0 & 100 & 0 & 0.3 \\
\hline$\varepsilon 2 / \varepsilon 3$ & 4 & 4 & 100 & 4 & 4 & 100 & 7.8 & 6.1 \\
\hline$\varepsilon 2 / \varepsilon 4$ & 1 & 1 & 100 & 1 & 1 & 100 & 2 & 0.7 \\
\hline$\varepsilon 3 / \varepsilon 3$ & 33 & 33 & 100 & 33 & 33 & 100 & 64.7 & 71.9 \\
\hline$\varepsilon 3 / \varepsilon 4$ & 13 & 13 & 100 & 13 & 13 & 100 & 25.5 & 19.3 \\
\hline$\varepsilon 4 / \varepsilon 4$ & 0 & 0 & 100 & 0 & 0 & 100 & 0 & 1.7 \\
\hline Total & 51 & 51 & & 51 & 51 & & 100 & 100 \\
\hline
\end{tabular}

Table 2: Comparison of genotypes between saliva and blood genomic DNA.

Genotyping results from Sanger sequencing and RFLP are shown. No subject had an E2/E2 genotype. Accuracy (\%): Concordance rate of genotyping results for blood and saliva samples. Genotype frequencies (\%) obtained in the current study and in a previous study by Eto et al. [6] is tabulated together

As stated in previous reports, genomic DNA extracted from saliva samples showed higher variability in concentration and quality than the genomic DNA extracted from blood samples [18]. DNA extracted from saliva is a mixture of human and nonhuman genomic DNA. According to Dawes et al., saliva contains approximately $4.3 \times 10^{5} / \mathrm{mL}$ epithelial cells and approximately $1.36 \times 10^{5} / \mathrm{mL}$ white blood cells. These cells are the major source of human genomic DNA. White blood cells provide undamaged genomic DNA. On the other hand, Endler et al. reported that approximately $40 \%$ of the epithelial cells in saliva do not provide intact genomic DNA [21]. Furthermore, saliva contains numerous bacteria (approximately $1.7 \times 10^{7} / \mathrm{mL}$ ); therefore, DNA extracted from saliva also contains bacterial DNA [22]. It is difficult to collect only undamaged human genomic DNA from saliva samples. This results in higher variability in the sample quality.

PCR is easily affected by contaminants, such as bacterial DNA, when the quality or concentration of the genomic DNA sample is low. As a result, incorrect or no PCR products may be obtained because of poor response. In general, the $A p o E$ gene has a high GC content and is located in a region which is difficult to amplify using PCR. In our study, we did not observe saliva genomic DNA in which low concentrations or quality negatively affected the PCR results. However, when genotyping is performed using saliva sample in place of blood sample, the quality of genomic DNA used as a template should be carefully investigated.

At least three alleles (E2, E3 and E4) could be identified by Sanger sequencing and RFLP methods. The sequence waveforms of all the samples were of sufficient quality for ApoE genotyping. However, in the RFLP method, many extra bands were observed. Special caution should be taken as the quality of genomic DNA may affect the genotyping results.

\section{Conclusion}

From this study, it was concluded that the genomic DNA extracted from saliva samples had higher variability in quality and concentration than that of genomic DNA extracted from blood samples. When genomic DNA extracted from saliva is used for genotyping of the ApoE gene, it is necessary to confirm if it is appropriate as a source before use. Nevertheless, in this validation, it was revealed that the $A P O E$ genotyping results from saliva were as accurate as those from blood.

\section{Acknowledgement}

The authors would like to thank Chinobu Mihara and Hitomi Takano (FANCL Corporation) for their excellent ethical support and execution of clinical trials as well as the subjects who participated in this study.

\section{Author Disclosure Statement}

No competing financial interests exist.

\section{References}

1. Das HK, McPherson J, Bruns GA, Karathanasis SK, Breslow JL (1985) Isolation characterization and mapping to chromosome 19 of the human apolipoprotein E gene. J Biol Chem 260: 6240-6247.

2. Corder EH, Saunders AM, Risch NJ, Strittmatter WJ, Schmechel DE, et al (1994) Protective effect of apolipoprotein E type 2 allele for late onset Alzheimer disease. Nat Genet 7: 180-184

3. Mahley RW, Nathan BP, Pitas RE (1996) Apolipoprotein E. Structure, function and possible roles in Alzheimer's disease. Ann N Y Acad Sci 777: 139-145.

4. Zannis VI, Kardassis D, Zanni EE (1993) Genetic mutations affecting human lipoproteins, their receptors, and their enzymes. Adv Hum Genet 21: 145-319.

5. Mahley RW (1988) Apolipoprotein E: cholesterol transport protein with expanding role in cell biology. Science 240: 622-630.

6. Eto M, Watanabe K, Ishii K (1986) A racial difference in apolipoprotein E allele frequencies between the Japanese and Caucasian populations. Clin Genet 30 $422-427$.

7. Strittmatter WJ, Saunders AM, Schmechel D, Pericak-Vance M, Enghild J et al. (1993) Apolipoprotein E: high-avidity binding to beta-amyloid and increased frequency of type 4 allele in late-onset familial Alzheimer disease. Proc Nat Acad Sci 90: 1977-1981.

8. Kukull WA, Schellenberg GD, Bowen JD, McCormick WC, Yu CE, et al. (1996) Apolipoprotein $\mathrm{E}$ in Alzheimer's disease risk and case detection: a case-control study. J Clin Epidemiol 49: 1143-1148.

9. Farrer LA, Cupples LA, Haines JL, Hyman B, Kukull WA, et al. (1997) Effects of age, sex and ethnicity on the association between apolipoprotein $E$ genotype and Alzheimer disease. A meta-analysis. APOE and Alzheimer Disease Meta Analysis Consortium. JAMA 278: 1349-1356.

10. Yoshizawa T, Yamakawa-Kobayashi K, Komatsuzaki Y, Arinami T, Oguni E, et al. (1994) Dose-dependent association of apolipoprotein E allele epsilon 4 with late-onset, sporadic Alzheimer's disease. Ann Neurol 36: 656-659.

11. Eichner JE, Dunn ST, Perveen G, Thompson DM, Stewart KE, et al. (2002) Apolipoprotein $E$ polymorphism and cardiovascular disease: A HuGE review. Am J Epidemiol 155: 487-495.

12. You H, Chen J, Zhou J, Huang H, Pan J, et al. (2015) Amplification refractory mutation system polymerase chain reaction versus optimized polymerase chain reaction restriction-fragment length polymorphism for apolipoprotein $E$ genotyping of majorly depressed patients. Mol Med Rep 12: 6829-6834.

13. Hixson JE, Vernier DT (1990) Restriction isotyping of human apolipoprotein E by gene amplification and cleavage with Hhal. J Lipid Res 31: 545-548.

14. Koch W, Ehrenhaft A, Griesser K, Pfeufer A, Müller J, et al. (2002) TaqMan systems for genotyping of disease-related polymorphisms present in the gene encoding apolipoprotein E. Clin Chem Lab Med 40: 1123-1131.

15. Saiki RK, Walsh PS, Levenson CH, Erlich HA (1989) Genetic analysis of amplified DNA with immobilized sequence-specific oligonucleotide probes. Proc Natl Acad Sci U S A 86: 6230-6234.

16. Hsu TM, Law SM, Duan S, Neri BP, Kwok PY (2001) Genotyping singlenucleotide polymorphisms by the invader assay with dual-color fluorescence polarization detection. Clin Chem 47: 1373-1377. 
Citation: Kushioka T, Ocho M, Ito Y, Yokokawa T, Yui K, et al. (2017) Evaluation of ApoE Genotyping Using Saliva-Derived DNA. J Clin Med Genomics 6: 149. doi: 10.4172/2472-128X.1000149

Page 4 of 4

17. Larsen F, Solheim J, Prydz H (1993) A methylated CpG island 3' in the apolipoprotein-E gene does not repress its transcription. Hum Mol Genet 2: 775-780.

18. Gudiseva HV, Hansen M, Gutierrez L, Collins DW, He J, et al. (2016) Saliva DNA quality and genotyping efficiency in a predominantly elderly population. BMC Med Genomics 9: 17

19. Livy A, Lye S, Jagdish CK, Hanis N, Sharmila V, et al. (2012) Evaluation of quality of DNA extracted from buccal swabs for microarray based genotyping. Indian J Clin Biochem 27: 28-33.
20. Tierney RT, Mansell JL, Higgins M, McDevitt JK, Toone N, et al. (2010) Apolipoprotein $\mathrm{E}$ genotype and concussion in college athletes. Clin $\mathrm{J}$ Sport Med 20: 464-468.

21. Endler G, Greinix H, Winkler K, Mitterbauer G, Mannhalter C (1999) Genetic fingerprinting in mouthwashes of patients after allogeneic bone marrow transplantation. Bone Marrow Transplant 24: 95-98.

22. Dawes C (2003) Estimates, from salivary analyses, of the turnover time of the oral mucosal epithelium in humans and the number of bacteria in an edentulous mouth. Arch Oral Biol 8: 329-336. 